Enlighten: Jurnal Bimbingan Konseling Islam

Volume 1 No 1 (Januari-Juni 2018) Hlm: 21-31

Tersedia online di http://journal.iainlangsa.ac.id/index.php/enlighten

ISSN 2622-8912

\title{
PENGARUH GENDER TERHADAP INTERAKSI SOSIAL DALAM PELAKSANAAN LAYANAN BIMBINGAN KELOMPOK SISWA SMP
}

\author{
${ }^{1}$ Nurul Azmi Saragih, ${ }^{2}$ Nur Asmah, ${ }^{3}$ Erma Putri \\ ${ }^{1}$ Program Studi Bimbingan dan Konseling UMN Al Washliyah Medan \\ ${ }^{2}$ Program Studi Bimbingan dan Konseling UMN Al Washliyah Medan \\ ${ }^{3}$ Program Studi Bimbingan dan Konseling UMN Al Washliyah Medan \\ Email: nurulazmisaragih@gmail.com
}

\begin{abstract}
Abstrak
Penelitian ini bertujuan untuk mengetahui pengaruh gender terhadap interaksi sosial dalam pelaksanaan layanan bimbingan kelompok pada siswa sekolah menengah pertama. Instrumen pengumpulan data yang digunakan untuk mengukur gender dan interaksi sosial adalah skala Likert. Gender diukur berdasarkan tipe gender yaitu maskulin, feminin dan androgini, pada interaksi sosial diukur berdasarkan syarat-syarat terjadinya interaksi yaitu kontak sosial dan komunikasi. Populasi dan sampel penelitian ini ada 78 orang. Analisis data yang digunakan adalah Regresi Linier Sederhana. Hasil penelitian menunjukkan bahwa gender berpengaruh positif terhadap interaksi sosial sebesar 0,226. Dan R Square sebesar 0,040, ini menunjukkan bahwa gender berpengaruh terhadap interaksi sosial dengan kontribusi sebesar 4\%. Uji hipotesis diperoleh nilai signifikan (sig) sebesar 0,077 yang lebih besar dari probabilitas 0,05 sehingga diambil keputusan untuk menerima $\mathrm{H} 0$ atau koefisien regresi yang diperoleh pada persamaan regresi dinyatakan tidak signifikan, berarti tidak terdapat pengaruh gender terhadap interaksi sosial dalam pelaksanaan layanan bimbingan kelompok pada siswa SMP.
\end{abstract}

Kata Kunci: Interaksi Sosial, Gender, Layanan Bimbingan Kelompok

\begin{abstract}
This study aims to determine the effect of gender on social interaction in the implementation of group counseling services in junior high school students. The data collection instrument used to measure gender and social interaction is the Likert scale. Gender is measured by gender type, masculine, feminine and androgyny, on social interaction measured based on requirements of interaction ie social contact and communication. Population and sample of this research there are 78 people. The data analysis used is Simple Linear Regression. The results showed that gender had a positive effect on social interaction of 0.226. And $R$ Square is 0,040, it shows that gender influence to social interaction with contribution of 4\%. Hypothesis test obtained significant value (sig) equal to 0.077 greater than probability 0,05 so taken decision to accept $\mathrm{HO}$ or regression coefficient obtained at regression equation is not significant, mean there is no influence of gender to social interaction in execution of service guidance group at junior high school students.
\end{abstract}

Keywords: Social Interaction, Gender, Group Guidance Services 


\section{PENDAHULUAN}

\section{A. Latar Belakang}

Pendidikan merupakan suatu sistem yang secara garis besar terdapat komponen masukan, proses dan keluaran. Pada sisi input maka kita akan melihat masukan dalam proses pendidikan tersebut seperti siswa (kemampuan akademis dan non akademis), guru (komponen, indeks prestasi, pengalaman) dan lain-lain. Pada sisi proses, maka kita akan melihat jalannya proses pembelajaran, kurikulum, penerapan teknologi dan lain sebagainya. Selanjutnya pada sisi keluaran maka kita akan melihat mutu tamatan yang dihasilkan.

Proses pembelajaran di sekolah tidak akan dapat lepas dari layanan bimbingan dan konseling. Program bimbingan konseling di sekolah tidak dapat dipisahkan dengan mata pelajaran yang lainnya. Bimbingan dan konseling menangani masalah-masalah atau hal-hal di luar bidang garapan pengajaran, tetapi secara tidak langsung menunjang tercapainya tujuan pendidikan dan pengajaran di sekolah itu. Bimbingan sebagai pendidikan dan perkembangan yang menekankan pada proses belajar yang sistematik. Sedangkan konseling menurut Walgito (2010: 63) adalah proses dimana seseorang yang ahli membantu individu dalam mengatasi hambatan perkembangan dirinya dengan wawancara menggunakan cara yang sesuai dengan keadaan individu tersebut.

Bimbingan dan konseling di sekolah terdapat beberapa bidang pelayanan BK salah satunya adalah layanan bimbingan kelompok. Tohirin (2007:170) menyebutkan bahwa bimbingan kelompok adalah suatu cara memberikan bantuan kepada individu (siswa) melalui kegiatan kelompok. Dalam bimbingan kelompok merupakan sarana untuk menunjang perkembangan optimal masing-masing siswa, yang diharapkan dapat mengambil manfaat dari pengalaman pendidikan ini bagi dirinya sendiri (dalam Winkel \& Sri Hastuti, 2004: 565).

Gender menurut Handayani dan Sugiarti (2002:6) adalah sifat yang melekat pada kaum laki-laki dan perempuan yang dibentuk oleh faktor-faktor sosial maupun budaya, sehingga lahir beberapa anggapan tentang peran sosial dan budaya laki-laki dan perempuan. Bentukan sosial atas laki-laki dan perempuan itu antara lain: perempuan dikenal sebagai makhluk yang lembut, cantik, emosional, dan keibuan. Sedangkan laki-laki dianggap kuat, rasional, jantan, dan perkasa. Sifat di atas dapat dipertukarkan dan berubah dari waktu ke waktu. Oleh karena itu dapat dikatakan bahwa gender dapat diartikan sebagai konsep sosial yang membedakan (dalam arti: memilih atau memisahkan) peran antara laki-laki dan perempuan. 
Individu dalam interaksi sosial dihadapkan pada suatu permasalahan yang kompleks. Menurut Moore (dalam Abdullah, 2003) pembagian kerja antara laki-laki dan perempuan berawal dari pengalaman awal hidup individu untuk bertahan hidup yang dilihat dari ketahanan fisik dan faktor biologis. Laki-laki memiliki ketahanan fisik yang lebih baik dibanding perempuan sehingga laki-laki menjadi lebih dominan perannya dalam interaksi sosial (Abdullah, 2003).

Dalam penelitian ini gender akan dikaitkan dengan pelaksanaan layanan bimbingan kelompok yang pada akhirnya akan berpengaruh terhadap interaksi sosial siswa. Menurut Macionis (dalam Prastikawati, 2003:41) interaksi merupakan "proses bertindak (aksi) dan membalas tindakan (reaksi) yang dilakukan seseorang dalam berhubungan dengan orang lain”. Interaksi sosial merupakan syarat utama terjadinya aktivitas-aktivitas sosial, oleh karena itu interaksi sosial merupakan hal yang sangat penting dalam proses pembelajaran hal ini sejalan dengan Undang-Undang Sisdiknas (Sistem Pendidikan Nasional) Nomor 20 pada bab I pasal (1) butir ke 20 dikatakan "Pembelajaran adalah proses interaksi peserta didik dengan pendidik dan sumber belajar pada suatu lingkungan belajar". Proses pembelajaran pada dasarnya adalah proses interaksi, baik interaksi antara guru dengan siswa maupun siswa dengan siswa, bahkan interaksi siswa dengan lingkungan.

Interaksi sosial kurang baik bagi kalangan sekolah menengah pertama dikarenakan keterbatasan peran gender yang menjadikan pelaksanaan layanan bimbingan kelompok di sekolah menjadi kurang efektif dan efisien. Siswa lebih senang melakukan layanan bimbingan kelompok dengan peran gender yang sejenis agar bisa menimbulkan interaksi sosial yang baik, seharusnya siswa tidak memilih gender yang sama ketika melaksanakan layanan bimbingan kelompok, tetapi persepsi siswa menjadikan peran gender sejenis untuk meningkatkan interaksi sosial agar isi dari kegiatan dapat terkomunikasikan lebih mendalam.

Berdasarkan latar belakang masalah dan pengamatan pada siswa dalam pelaksanaan layanan bimbingan kelompok di SMP Al Falah Medan, maka peneliti tertarik mengadakan penelitian yang berkaitan dengan pengaruh gender terhadap interaksi sosial dalam pelaksanaan layanan bimbingan kelompok pada siswa. 


\section{METODE PENELITIAN}

Desain penelitian yang digunakan dalam penelitian ini adalah pendekatan kuantitatif dengan metode eksperimen. Dalam penelitian ini, terdapat dua variabel penelitian yang akan diteliti yaitu variabel gender sebagai variabel bebas serta variabel interaksi sosial sebagai variabel terikat. Teknik yang akan digunakan dalam pengumpulan data pada penelitian ini adalah dengan skala Likert.

Dalam penelitian ini, populasinya yaitu siswa SMP Al-Falah Medan dan jumlah siswa tersebut adalah 78 siswa yang terdiri dari kelas VII sebanyak 24 siswa, kelas VIII sebanyak 25 siswa dan kelas IX sebanyak 29 siswa, sedangkan sampel penelitian Arikunto (2010), menjelaskan apabila subjek kurang dari 100 lebih baik diambil semua, maka sampel dalam penelitian ini adalah 78 siswa.

Metode analisis data yang digunakan pada penelitian ini adalah Regresi Linier Sederhana. Sebelumnya, dilakukan uji validitas dan reliabilitas skala dengan menggunakan rumus Pearson Product Moment dan Alpha Cronbach. Analisis data dilakukan dengan menggunakan bantuan program komputer SPSS 17 for windows.

\section{HASIL DAN PEMBAHASAN}

\section{Hasil Penelitian}

Teknik analisis data yang digunakan dalam penelitian ini adalah Analisis Regresi Linier Sederhana dimana teknik analisis ini digunakan sesuai dengan hipotesa, yakni ingin melihat apakah ada pengaruh gender terhadap interaksi sosial dalam pelaksanaan layanan bimbingan kelompok pada siswa SMP. Sebagaimana layaknya penelitian ilmiah, maka data yang akan diolah untuk pengujian hipotesis, harus melalui tahapan uji asumsi yang sesuai dengan orientasi penelitian. 
a. Uji Normalitas

\begin{tabular}{|ll|r|}
\hline \multicolumn{2}{|c|}{ One-Sample Kolmogorov-Smirnov Test } \\
\hline $\mathrm{N}$ & $\begin{array}{c}\text { Unstandardized } \\
\text { Residual }\end{array}$ \\
Normal Parameters & \\
& & 78 \\
& Mean & .0000000 \\
Most Extreme Differences & Std. Deviation & Absolute \\
& Positive & .25710017 \\
& Negative & .065 \\
Kolmogorov-Smirnov Z & &. .065 \\
Asymp. Sig. (2-tailed) & & .571 \\
\end{tabular}

a. Test distribution is Normal.

b. Calculated from data.

Histogram

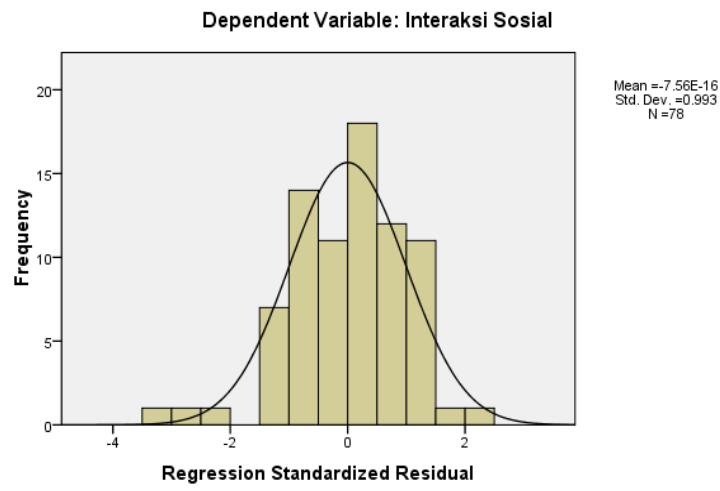

Gambar 1. Kurva Normalitas Normal P-P Plot of Regression Standardized
Residual

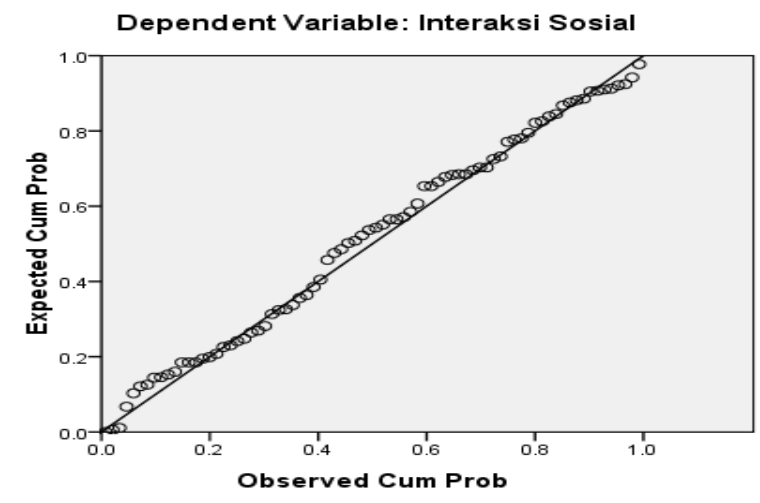

Gambar 2. Grafik Normalitas 
Dari hasil di atas, diperoleh nilai signifikansi sebesar 0,900 yang lebih besar dari 0,05, sehingga dapat disimpulkan bahwa data dalam penelitian ini berdistribusi normal.

\section{b. Uji Linieritas}

Hasil analisis menunjukkan bahwa variabel bebas (Gender) mempunyai hubungan yang linier terhadap variabel terikat (Interaksi Sosial). Sebagai kriterianya apabila p beda < 0,05 maka dinyatakan mempunyai derajat hubungan yang linier.

\begin{tabular}{|c|c|c|c|c|c|c|c|}
\hline \multicolumn{8}{|c|}{ ANOVA Table } \\
\hline & & & $\begin{array}{l}\text { Sum of } \\
\text { Squares }\end{array}$ & $d f$ & $\begin{array}{c}\text { Mean } \\
\text { Square }\end{array}$ & $\mathrm{F}$ & Sig. \\
\hline \multirow{5}{*}{$\begin{array}{l}\text { Interaksi } \\
\text { Sosial * } \\
\text { Gender }\end{array}$} & Between & (Combined) & 1242.464 & 24 & 51.769 & 1.445 & .132 \\
\hline & Groups & Linearity & 127.196 & 1 & 127.196 & 3.549 & .065 \\
\hline & & Deviation from Linearity & 1115.268 & 23 & 48.490 & 1.353 & .181 \\
\hline & Within Gr & & 1899.382 & 53 & 35.837 & & \\
\hline & Total & & 3141.846 & 77 & & & \\
\hline
\end{tabular}

Dari hasil di atas, diperoleh nilai signifikansi 0,181 yang lebih besar dari 0,05. Hal ini berarti bahwa terdapat hubungan linier secara signifikan antara variabel gender dengan variabel interaksi sosial.

\section{c. Uji Regresi Linier Sederhana}

Pengujian hipotesis dalam penelitian ini dilakukan dengan menggunakan teknik regresi linier sederhana dengan bantuan program SPSS 17.0 for windows. Dengan hasil data sebagai berikut:

Coefficients $^{\mathrm{a}}$

\begin{tabular}{|c|c|c|c|c|c|c|}
\hline \multirow{2}{*}{\multicolumn{2}{|c|}{ Model }} & \multicolumn{2}{|c|}{$\begin{array}{l}\text { Unstandardized } \\
\text { Coeff icients }\end{array}$} & \multirow{2}{*}{$\begin{array}{c}\text { Standardized } \\
\text { Coefficients } \\
\text { Beta }\end{array}$} & \multirow[b]{2}{*}{$t$} & \multirow[b]{2}{*}{ Sig. } \\
\hline & & B & Std. Error & & & \\
\hline \multirow[t]{2}{*}{1} & (Constant) & 70,313 & 7,548 & & 9,315 &, 000 \\
\hline & GENDER & ,226 & ,126 & ,201 & 1,791 & ,077 \\
\hline
\end{tabular}

a. Dependent Variable: INTERAKSI SOSIAL 
Sehingga hasil persamaan regresi yang diperoleh adalah:

$$
\mathrm{Y}=70,313+0,226 \mathrm{X}
$$

Harga 70,313 merupakan nilai konstanta (a) yang menunjukkan bahwa jika tidak ada gender, maka interaksi sosial akan mencapai 70,313. Adapun harga 0,226 merupakan koefisien regresi yang menunjukkan bahwa setiap ada penambahan 1 angka untuk gender, maka akan ada interaksi sosial sebesar 0,226.

Dari persamaan di atas, diperoleh koefisien regresi yang menggambarkan pengaruh gender terhadap interaksi sosial sebesar $\mathrm{R}=0,226$. Sehingga dapat disimpulkan bahwa gender berpengaruh positif terhadap interaksi sosial.

Hipotesis yang diajukan pada penelitian ini adalah:

Ha: Terdapat pengaruh gender terhadap interaksi sosial dalam pelaksanaan layanan bimbingan kelompok pada siswa SMP.

Ho: Tidak terdapat pengaruh gender terhadap interaksi sosial dalam pelaksanaan layanan bimbingan kelompok pada siswa SMP.

Data di bawah ini berdasarkan pada hipotesis yang diajukan pada penelitian:

ANOVA

\begin{tabular}{|c|c|c|c|c|c|c|}
\hline \multicolumn{2}{|c|}{ Model } & Sum of Squares & $d f$ & Mean Square & $F$ & Sig. \\
\hline \multirow[t]{3}{*}{1} & Regression & 127.196 & 1 & & 3.207 & $.077^{a}$ \\
\hline & Residual & 3014.650 & 76 & 39.666 & & \\
\hline & Total & 3141.846 & 77 & & & \\
\hline
\end{tabular}

a. Predictors: (Constant), Gender

b. Dependent Variable: Interaksi Sosial

Berdasarkan hasil data di atas diperoleh nilai signifikan ( sig) sebesar 0,077 yang lebih besar dari probabilitas 0,05 sehingga diambil keputusan untuk menerima Ho. Hal ini menyatakan bahwa tidak ada pengaruh gender terhadap interaksi sosial dalam pelaksanaan 
layanan bimbingan kelompok pada siswa SMP. Atau dengan kata lain, koefisien regresi yang diperoleh pada persamaan regresi di atas dinyatakan tidak signifikan.

Hasil dari pengaruh gender terhadap interaksi sosial adalah:

Tabel 8. Hasil R Square

Model Summary

\begin{tabular}{|l|r|r|r|r|}
\hline Model & $\mathrm{R}$ & $\mathrm{R}$ Square & $\begin{array}{c}\text { Adjusted } \\
\mathrm{R} \text { Square }\end{array}$ & $\begin{array}{c}\text { Std. Error of } \\
\text { the Estimate }\end{array}$ \\
\hline 1 &, $201^{\mathrm{a}}$ &, 040 &, 028 & 6,298 \\
\hline
\end{tabular}

a. Predictors: (Constant), GENDER

Berdasarkan hasil data di atas, diperoleh nilai R Square sebesar 0,040 yang menyatakan bahwa pengaruh gender terhadap interaksi sosial sebesar $4 \%$, sedangkan $96 \%$ dipengaruhi oleh variabel lain yang tidak diteliti pada penelitian ini. Dari hasil analisis di atas, dapat ditarik kesimpulan bahwa gender berpengaruh positif terhadap interaksi sosial dengan total pengaruh sebesar $4 \%$.

\section{Pembahasan}

Berdasarkan hasil analisis data yang dilakukan dengan Regresi Linier Sederhana menunjukkan bahwa gender berpengaruh positif terhadap interaksi sosial sebesar 0,226. Dan R Square sebesar 0,040, ini menunjukkan bahwa gender berpengaruh terhadap interaksi sosial dengan kontribusi sebesar 4\%, sehingga pada uji hipotesis, Ho diterima dengan asumsi tidak terdapat pengaruh gender terhadap interaksi sosial dalam pelaksanaan layanan bimbingan kelompok pada siswa SMP, menurut Sukardi (2008: 23) hal yang mendasari berlangsungnya interaksi sosial adalah adanya hubungan antara individu dalam melakukan komunikasi dengan lingkungan disekitarnya. Menurut Winkel (Ahmadi 2002: 29) interaksi sosial merupakan suatu bentuk pergaulan dimasyarakat yang mempunyai rambu-rambu atau etika dalam pergaulan dimasyarakat. 
Sehingga dapat disimpulkan bahwa gender hanya menjadi bagian dalam interaksi sosial, karena gender menurut Handayani dan Sugiarti (2008) adalah suatu konsep sosial yang membedakan (dalam arti memilih atau memisahkan) peran antara laki-laki dan perempuan. Menurut Wiliam (2006) gender memuat perbedaan fungsi dan peran sosial laki-laki dan perempuan, yang terbentuk oleh lingkungan. Gender sama sekali berbeda dengan jenis kelamin. Gender bukan jenis kelamin.

Berdasarkan definisi di atas, menunjukkan bahwa dapat disimpulkan interaksi sosial adanya hubungan individu dalam melakukan komunikasi dengan lingkungan disekitarnya, makna dari kata lingkungan disini menggambarkan gender sebagai peran sosial laki-laki dan perempuan.

Dalam penelitian ini terdapat pelaksanaan layanan bimbingan kelompok sebagai penguat data penelitian, sesuai dengan hal yang diteliti yaitu "Pengaruh Gender Terhadap Interaksi Sosial Dalam Pelaksanaan Layanan Bimbingan Kelompok Siswa SMP”.

Berdasarkan hasil pelaksanaan layanan bimbingan kelompok yang dilakukan dengan tiga kelompok dapat terlihat pada lampiran laporan pelaksanaan layanan, dengan kesimpulan bahwa gender berpengaruh terhadap interaksi sosial dengan kontribusi sebesar $4 \%$, sehingga menjadi dasar dalam pelaksanaan layanan bimbingan kelompok, interaksi sosial hanya dipengaruhi $4 \%$ saja dari gender, sedangkan $96 \%$ mungkin dari faktor lain, sebab Prayitno (1995: 178) mengemukakan bahwa Bimbingan kelompok adalah Suatu kegiatan yang dilakukan oleh sekelompok orang dengan memanfaatkan dinamika kelompok. Artinya, semua peserta dalam kegiatan kelompok saling berinteraksi, bebas mengeluarkan pendapat, menanggapi, memberi saran, dan lain-lain sebagainya; apa yang dibicarakan itu semuanya bermanfaat untuk diri peserta yang bersangkutan sendiri dan untuk peserta lainnya. 
Sedangkan pelaksanaan layanan bimbingan kelompok pada penelitian ini terlihat pada laporan layanan masih banyak siswa yang tidak berinteraksi dengan baik, tidak bebas mengeluarkan pendapat, tidak banyak yang menanggapi serta memberi saran, sesuai pernyataan Prayitno di atas jelas data menunjukkan bahwa gender berpengaruh positif terhadap interaksi sosial sebesar $\mathrm{R}=0,226$, dengan $\mathrm{R}$ Square sebesar $=0,040$ dengan total pengaruh gender terhadap interaksi sosial sebesar $4 \%$, hanya sedikit kontribusi pengaruh dari kedua variabel tersebut, sehingga pada uji hipotesis, Ho diterima dengan makna koefisien regresi yang diperoleh pada persamaan regresi linier sederhana dinyatakan tidak signifikan atau tidak terdapat pengaruh gender terhadap interaksi sosial dalam pelaksanaan layanan bimbingan kelompok pada siswa SMP.

\section{KESIMPULAN}

Dari persamaan regresi linier sederhana $Y=70,313+0,226 X$, diperoleh koefisien regresi yang menggambarkan pengaruh gender terhadap interaksi sosial sebesar $\mathrm{R}=0,226$. Sehingga dapat disimpulkan bahwa gender berpengaruh positif terhadap interaksi sosial. Harga 70,313 merupakan nilai konstanta (a) yang menunjukkan bahwa jika tidak ada gender, maka interaksi sosial akan mencapai 70,313. Adapun harga 0,226 merupakan koefisien regresi yang menunjukkan bahwa setiap ada penambahan 1 angka untuk gender, maka akan ada interaksi sosial sebesar 0,226.

Berdasarkan hasil data uji hipotesis diperoleh nilai signifikan (sig) sebesar 0,077 yang lebih besar dari probabilitas 0,05 sehingga diambil keputusan untuk menerima $\mathrm{H} 0$. Hal ini menyatakan bahwa tidak ada pengaruh gender terhadap interaksi sosial dalam pelaksanaan layanan bimbingan kelompok pada siswa sekolah menengah pertama, atau dengan kata lain, koefisien regresi yang diperoleh pada persamaan regresi di atas dinyatakan tidak signifikan. 


\section{DAFTAR RUJUKAN}

Abdullah, I. (2003). Penelitian Berwawasan Gender dalam Ilmu Sosial. Humaniora, 10 (3), 265-275. (versi elektronik)

Anggota IKAPI. (2010). Undang-Undang SISDIKNAS (Sistem Pendidikan Nasional). Bandung: Fokusmedia

Arikunto, S. 2010. Prosedur Penelitian Suatu Pendekatan Praktik. Jakarta: Rineka Cipta

Handayani, Trisakti dan Sugiarti. (2002). Konsep dan Teknik Penelitian Gender. Malang: UMM Press

Prastikawati Desi. (2013). Buku Ajar Sosiologi SMA/MA Kelas X. Surakarta: Citra Pustaka

Prayitno. 2012. Jenis Layanan dan Kegiatan Pendukung Konseling. Padang: PPK BK FIP UNP

Walgito, B. (2003). Psikologi Sosial (Suatu Pengantar). Yogyakarta: Andi

William, de Vries Dede. (2006). Gender Bukan Tabu: Catatan Perjalanan Fasilitasi

Winkel, W.S. dan Sri Hastuti. 2004. Bimbingan dan Konseling di Institusi Pendidikan. Yogyakarta: Media Abadi 